\title{
Nutritive value of rapeseed meal from two Brassica campestris varieties for growing pigs
}

\author{
Maija-Liisa Salo \\ Department of Animal Husbandry, University of Helsinki, 00710 Helsinki 71
}

\begin{abstract}
The digestibility and nutritive value of two rapeseed meals (Brassica campestris), one prepared from the medium-glucosinolate varieties Span and Torch, and the other from a low-glucosinolate variety Candle, were determined for three pigs weighing about $45 \mathrm{~kg}$. The pigs received $1600 \mathrm{~g}$ barley and $600 \mathrm{~g}$ rapeseed meal daily.

The composition of the Candle meal was better than that of Span-Torch and its digestibility and nutritive value higher $(\mathrm{P}<0.01)$. When the fat content of Candle meal was corrected to the $1.5 \%$ level of Span-Torch meal, the ME values were 13.6 and $10.4 \mathrm{MJ} / \mathrm{kg} \mathrm{DM}$, the $\mathrm{NE}$ values 1.01 and $0.78 \mathrm{FU} / \mathrm{kg} \mathrm{DM}(\mathrm{FU}=0.7 \mathrm{~kg}$ starch), and the DCP values 318 and $248 \mathrm{~g}$ DCP/kg DM for Candle and Span-Torch, respectively $(\mathrm{P}<0.01)$. The difference in the nitrogen balance was also significant $(\mathrm{P}<0.01)$. Thus the Candle meal has about $30 \%$ higher nutritive value for pigs than the SpanTorch meal.
\end{abstract}

\section{Introduction}

In the new rape varieties the content of glucosinolates has been reduced by breeding to almost one tenth of the original value, making possible increased levels of rapeseed meal in livestock rations. Nevertheless, not even a lowglucosinolate rapeseed meal has been found equal to soybean meal for growing pigs (Castell 1977, Kendall 1977, McKinnon and Bowland 1977, Kennelly et al. 1978) or laying hens (SLINGER et al. 1978) when fed in high concentrations. The present recommendations for growing pigs are $10-14 \%$ of the ration (Sarwar and Bowland 1976, Alaviuhkola 1979). For ruminants, on the other hand, good results have been reported even at $25-30 \%$ level of the concentrate (BUSh et al. 1978, PApas et al. 1978, SyrJälä and Nieminen 1979), and for turkeys up to $30 \%$ of the diet (SALMon 1979).

In the present study the digestibility and nutritive value of two rapeseed meals (Brassica campestris), one prepared from the low-glucosinolate Candle, the other from a mixture of medium-glucosinolate varieties, Span and Torch, were determined with three pigs, weighing about $45 \mathrm{~kg}$. 


\section{Materials and methods}

The two investigated rapeseed meals were a domestic mixture of mediumglucosinolate Span and Torch varieties and the low-glucosinolate Candle meal imported from Canada. Table 1 shows their compositions.

The digestibility trials were performed for three castrated pigs weighing about $45 \mathrm{~kg}$. The pigs were kept in digestibility cages in a room maintained at about $20^{\circ} \mathrm{C}$.

Table 1. Composition of rapeseed meals, \% of DM.

\begin{tabular}{|c|c|c|}
\hline & Span-Torch & Candle \\
\hline 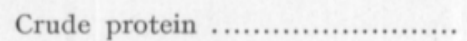 & 36.8 & 39.4 \\
\hline 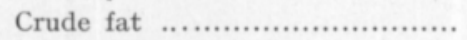 & 1.5 & 5.0 \\
\hline 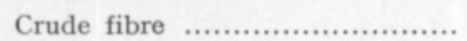 & 15.7 & 10.9 \\
\hline 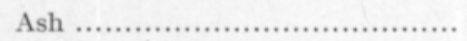 & 11.2 & 7.2 \\
\hline 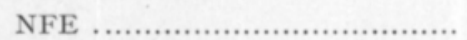 & 34.8 & 37.5 \\
\hline Glucosinolates ........................ & 2.1 & 0.4 \\
\hline 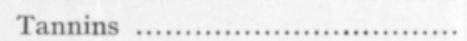 & 1.5 & 1.7 \\
\hline
\end{tabular}

The daily ration consisted of $1600 \mathrm{~g}$ barley meal and $600 \mathrm{~g}$ rapeseed meal, plus added minerals and vitamins according to standards. The animals were fed twice daily. The different components were weighed separately and mixed with two volumes of water. The pigs ate the ration immediately and were then offered water.

The preliminary period was ten days and the collection period five days. The faeces and urin€ were collected in the morning and samples of fixed amount were taken for analysis. Sulphuric acid was added to the urine collection pail to keep the acidity under $\mathrm{pH} 3$. At the end of the collection period spatterings of feed were collected from a plastic sheet placed in front of the through, and subtracted from the total amount of feed given.

The dry matter determinations were made at $103^{\circ} \mathrm{C}$, and the samples for analysis dried in vacuum at $50^{\circ} \mathrm{C}$. Feeds and faeces were milled using a sieve of $0.5 \mathrm{~mm}$. The analyses were made according to standard procedures.

The digestibility of barley was determined in a separate trial and the digestibility of the rapeseed meals calculated by subtraction.

The metabolizable energy and net energy values were calculated using factors and models of NJF's Feed Tables (AnON. 1969). The differences between the two meals were tested by the t-test.

\section{Results and discussion}

The digestibility coefficients and calculated energy and DCP values are set out in Tables 2 and 3 . 
Table 2. Digestibility coefficients of rapeseed meals.

\begin{tabular}{|c|c|c|}
\hline & Span-Torch & Candle \\
\hline Organic matter ............... & $67.4 \pm 2.0^{* *}$ & $83.5 \pm 3.7^{* *}$ \\
\hline Crude protein ............... & $67.3 \pm 2.1 * *$ & $80.6 \pm 4.1^{* *}$ \\
\hline Crude fat $\ldots \ldots \ldots \ldots \ldots \ldots \ldots$ & $64.2 \pm 8.0^{*}$ & $80.1 \pm 5.3^{*}$ \\
\hline Crude fibre $. . . \ldots \ldots \ldots \ldots \ldots . . . . .$. & $46.4 \pm 3.0^{*}$ & $60.8 \pm 6.2^{*}$ \\
\hline 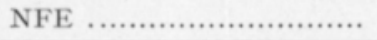 & $71.0 \pm 1.8^{* *}$ & $87.8 \pm 3.3^{* *}$ \\
\hline
\end{tabular}

$*=\mathrm{P}<0.05, * *=\mathrm{P}<0.01, * * *=\mathrm{P}<0.001$.

Table 3. Nutritive values of rapeseed meals and nitrogen balaces of pigs in the trials.

\begin{tabular}{lcc}
\hline & Span-Torch & Candle \\
\hline Metabolizable energy (ME), MJ/kg DM & $10.43 \pm 0.33^{* * *}$ & $\left.14.23 \pm 0.67^{* * * 2}\right)$ \\
Net energy (NE), FU/kg DM $)$ & $0.78 \pm 0.03^{* * *}$ & $\left.1.07 \pm 0.05^{* * * 2}\right)$ \\
Digestible crude protein (DCP), g/kg DM & $248 \pm 8^{* * *}$ & $318 \pm 16^{* * *}$ \\
Nitrogen balances, g N/d & $21.2 \pm 0.9^{* *}$ & $26.5 \pm 0.6^{* *}$ \\
\hline
\end{tabular}

1) $\mathrm{FU}=0.7 \mathrm{~kg}$ starch

2) When corrected to $1.5 \%$ fat content, the values for Candle are $13.6 \mathrm{MJ}$ and 1.01 FU/kg DM.

The new Canadian rape variety, Candle, has a thinner seed coat than the older varieties. This appeared as a lower content of crude fibre and ash, and a higher content of crude protein. The oil had also been less thoroughly extracted from the Candle seeds than the Span-Torch seeds and the meal contained more fat (Table 1).

The better composition of the Candle meal is reflected in the higher digestibility and feed values (Tables 2 and 3 ), the differences between the two meals being highly significant for several nutritive characteristics. To achieve a more exact comparison, energy values based on a $1.5 \%$ fat content were calculated for Candle meal. The corrected values were then 13.6 MJ ME and $1.01 \mathrm{FU} / \mathrm{kg} \mathrm{DM}$, and the difference still significant $(\mathrm{P}<0.01)$. The energy value of the Candle meal thus was similar to barley and about $30 \%$ higher than that of the Span-Torch meal. The tannin content was low in both meals (cf. FEnwick and Hoggan 1976) and could not explain the great difference between digestibilities. Furthermore, the Span-Torch meal was ground more finely than the Candle meal, which was of medium coarseness.

When the results are compared with those given in the Feed Tables for pigs, the digestibility of Span-Torch meal is found to be somewhat lower, and that of Candle meal a little higher (Breirem and Homb 1970, Nehring et al. 1970, Eriksson et al. 1972). The lower value for the former is explained by the fact that the mrapeseed mealn of the Feed Tables usually means $B$. napus meal, which has a higher nutritive value than the meal obtained from the older $B$. campestris varieties. The nutritive value obtained here for Candle was high, though even higher values have been reported for some $B$. campestris meals 
(Bailey and Hill 1975). Furthermore, Candle meal has been found to be equal to Tower meal (B. napus) for hens (MuzTar et al. 1978) and even better than Tower for ruminants (Bush et al. 1978). According to the present study, it is also a little better feed for pigs than the B. napus meals given in the Feed Tables.

The superiority of Candle meal over Span-Torch meal appeared also in the DCP values and nitrogen balances of the pigs $(\mathrm{P}<0.01)$. The pigs received the same amounts of feed in the two trials, but owing to the different energy values of rapeseed meals, they received daily $0.17 \mathrm{FU}$ and $38 \mathrm{~g}$ DCP more in the Candle diet than in the Span-Torch diet. This made possible a higher daily gain and nitrogen retention.

Span and Torch are the rape varieties most commonly cultivated in Finland. The meals are marketed only as a mixture, and the investigated meal was a sample of this. Candle is a newer variety, cultivated in Finland only at Research Stations. It has been found to give about $20 \%$ lower crop yield than Span and Torch varieties (Hovinen 1979). The about $30 \%$ higher energy and DCP values of the meal, as found in the present study, should help to compensate for the lower crop yield, however.

\section{REFERENCES}

AlaviuнкоцA, T. 1979. Rapsi- ja rypsijauhot sikojen rehuna. Käytännön maamies 4/1979: $75-76$.

ANoN. 1969. Nordisk Jordbrugsforskning. Fodermiddeltabel. 40 p. Gjovik.

BAILEY, H. S. \& Hill, D. C. 1975. Nutritional evaluation of low and high fibre fractions of rapeseed meal using chickens and pigs. Can. J. Anim. Sci .55: 223-232.

Breirem, K. \& Номв, T. 1970. Førmidler og fôrkonservering. 459 p. Gjôvik.

Bush, R. R., Nicholson, J. W. G., Macintyre, T. M. \& McQueen, R. E. 1978. A comparison of Candle and Tower rapeseed meals in lamb, sheep and beef steer rations. Can. J. Anim. Sci. 58: 369-376.

Castell, A. G. 1977. Effects of virginiamycin on the performance of pigs fed barley diets supplemented with soybean meal or low-glucosinolate rapeseed meal. Can. J. Anim. Sci. 57: $313-320$.

Eriksson, S., Sanne, S. \& Tномке, S. 1972. Fodermedlen. 299 p. Borås.

Fenwick, R. G. \& Hoggan, S. A. 1976. The tannin content of rapeseed meals. Br. Poult. Sci. 17: 59-62.

Hovinen, S. 1979. Öljykasvit valkuaishuoltomme kulmakivinä. Käytännön maamies 3/1979: $21-23$.

Kendall, J. D. 1977. Nutritive value of Tower rapeseed meal. Feedstuffs 49 no $37: 12$.

Kennelly, J. J., Aherne, F. X. \& Lewis, A. J. 1978. The effects of levels of isolation, or varietal differences in high fibre hull fraction of low glucosinolate rapeseed meals on rat or pig performance. Can. J. Anim. Sci. 58: 743-752.

McKinnon, P. J. \& Bowland, J. P. 1977. Comparison of low glucosinolate - low erucic acid rapeseed meal (cv. Tower), commercial rapeseed meal and soybean meal as sources of protein for starting, growing and finnishing pigs and young rats. Can. J. Anim. Sci. 57: $663-678$.

Muztar, A. J., Likuski, H. J. \& Slinger, S. J. 1978. Metabolizable energy content of Tower and Candle rapeseeds and rapeseed meals determined in two laboratories. Can. J. Anim. Sci. 58: 485-492.

Nehring, K., Beuer, M. \& Hoffmann, B. 1970. Futtermitteltabellenwerk. 460 p. Berlin. 
Papas, A., Ingalls, J. R. \& CAnsfield, P. 1978. Effect of Tower and 1821 rapeseed meals and Tower gums on milk yield, milk composition and blood parameters of lactating dairy cows. Can. J. Anim. Sci. 58: 671-679.

Sarwar, G. \& Bowland, J. P. 1976. Protein quality evaluation of low glucosinolate - low erucic acid rapeseed meal and unprocessed faba beans in young pigs. J. Nutr. 106: $350-361$.

Slinger, S. J., Summers, J. D. \& Leeson, S. 1978. Utilization of meal from a new rapeseed variety, Brassica campestris cv. Candle, in layer diets. Can. J. Anim. Sci. 58: 593-596.

SyrJäLÄ, L. \& Nieminen, M. 1979. Rapsirouhe, urea ja lipeäolki lihanaudan rehuna. Koetoim. ja käytäntö 5/1979: 18-19.

Ms received September 28, 1979.

\section{SELOSTUS}

\section{Rypsijauhojen sulavuus ja rehuarvo lihasialla}

Maija-Lirsa Salo

Helsingin yliopiston kotieläintieteen laitos, 00710 Helsinki 71

Kahden rypsijauhon (Brassica campestris), kotimaisen glukosinolaattipitoisuudeltaan keskitasoon kuuluvista Span ja Torch lajikkeista peräisin olevan seoksena markkinoitavan jauhon, ja Kanadassa tuotetun vähäglukosinolaattisen Candle-jauhon sulavuus määritettiin noin 45 kiloisilla lihasioilla. Siat saivat $1600 \mathrm{~g}$ ohraa ja $600 \mathrm{~g}$ rypsijauhoa päivässä.

Candle-jauhon koostumus oli Span-Torch-jauhoa parempi. Myös sen sulavuus ja rehuarvo osoittautui selvästi paremmaksi. Kun Candle-jauhon rasvapitoisuus korjataan SpanTorch-jauhon kanssa samaksi, $1.5 \%$ :ksi, saadaan seuraavat rehuarvot järjestyksessä Candle, Span-Torch: muuntokelpoinen energia 13.6 ja $10.4 \mathrm{MJ} \mathrm{ME} / \mathrm{kg}$ ka, ry-arvo 1.01 ja $0.78 \mathrm{ry} / \mathrm{kg}$ ka sekä srv-arvo 318 ja $248 \mathrm{~g} \mathrm{srv} / \mathbf{k g}$ ka. Candle-jauhon paremmuus näkyi myös typpitaseissa, mitkä olivat 26.5 ja $21.2 \mathrm{~g} \mathrm{~N} / \mathrm{pv}$. Kaikki erot olivat merkitseviä $(\mathrm{P}<0.01)$. Candle-jauhon rehuarvo sialla oli siten noin $30 \%$ Span-Torch-jauhon arvoa parempi, vaikka rasvapitoisuus korjattiin samaksi. 